\title{
Introduction to the special issue on User Experience in e-Business Environments
}

\author{
Christos K. Georgiadis • Patrick Y. K. Chau
}

Published online: 14 February 2013

(C) Springer-Verlag Berlin Heidelberg 2013

In the emerging global economy, e-commerce and e-business have increasingly become a necessary component of business strategy and a strong catalyst for economic development. Various applications of e-commerce are continually affecting trends and prospects for business over the Internet, including e-tailing, online publishing and online bidding.

Eventually, with the rising proliferation of Internet, the customers' expectations and demands have been changed. Customers seek to buy products and services in more competitive prices, without compromising the offered quality.

A lot of research has been conducted worldwide on e-commerce, as it is undoubtedly a growing market and its applications represent a particularly highgrowth area in business sector. However, there has been little consideration on examining and evaluating user experience (expectations, perceptions, satisfaction) in the e-business context. The customer's experience is a very important factor for the success of any e-commerce practice because it influences the customer's perceptions of value and product/service quality, and therefore is affecting customer loyalty and retention.

Customers' perceptions are formed subsequent to their experience of the services received from an organization. Customers' expectations revolve around their conviction about the products and services that they receive from the organization. Customers evaluate the service perceive performance, grounding on their expectation that they already have about the service of the company. Customers assigned

\section{K. Georgiadis $(\bowtie)$}

Department of Applied Informatics, University of Macedonia, 156 Egnatia Street, 54006 Thessaloniki, Greece e-mail: geor@uom.edu.gr; gxri@acm.org

P. Y. K. Chau ( $\bowtie)$

School of Business, Faculty of Business and Economics,

The University of Hong Kong, Pokfulam, Hong Kong

e-mail: pchau@business.hku.hk 
their perception of services that firm's serves for their customers, according their experience of the process of firm's services delivered.

Successful e-commerce user experience depends on a large number of factors. It is the total customer experience that influences the customers' perceptions of value and service quality, and which consequently affects customer loyalty. Considering that an online customer is not simply a shopper but also an information technology (IT) user (Pathasarathy and Bhattacherjee 1998; Cho and Park 2001), one can argue that the online experience is a more complicated issue than the physical shopping experience. For example, the identification of the relative importance of firm's reputation and Web site trust, as well as their potential synergies for trust-building in this impersonal online environment is a critical concern (Tams 2010).

The adoption patterns for new technology such as e-commerce and mobile services are essential to understand for developing them further. Various frameworks and models have been developed to investigate the nature and determinants of IT acceptance and adoption. Of major influence was the technology acceptance model (TAM), proposed by Davis (Davis 1989; Davis et al. 1989), which claims that users evaluate the system based on its ease of use and perceived usefulness. If the system is easy to use and useful, a user would have a positive attitude toward the system which in turn causes a user's actual intention to use. Then, the intention creates a user's decision to use the system. The TAM has been continuously studied and expanded: according to many authors (King and He 2006) the TAM measures are highly reliable and may be used in a variety of contexts. A significant expansion (Venkatesh et al. 2003), aiming to integrate the main competing user acceptance models, was the formulation of the Unified Theory of Acceptance and Use of Technology (UTAUT).

IT acceptance theories and models have frequently been used as the theoretical basis in many empirical studies for predicting consumers' usage intention and behavior in the technology context (Park and Chen 2007; Lee et al. 2009; Lu and Su 2009; Chen et al. 2010, 2011).

Hence, in order to predict users' attitudes toward e-commerce services or products and moreover to improve the quality and extend the functions of e-commerce services, we should investigate two primary research streams - the user satisfaction literature and the technology acceptance literature. Moreover, these two aspects should be developed and integrated for evaluating users' experience.

In recognition of this need, seven papers are selected (of 16 in total peerreviewed submissions) to this special issue. These papers illustrate some of the assessment of user experience as a particular perspective within Information Systems (IS) and e-Commerce Technology research. Additional reflections to the IT acceptance models, based on expectation confirmation theory (ECT), transaction cost economics (TCE), flow theory (FT), regulatory fit theory (RFT) and brandingassociation-trust model (BATM), are taken into consideration.

Furthermore, the above papers reflect some of the most discussed terms and aspects in the areas of e-business and e-commerce, such as on-line auctions, factors affecting users' purchases intention and behavior concerning the usage of e-commerce and/or mobile services. 
More specifically, Wang, Oh, Wang and Yuan address issues of free trial which has been widely used by IT industry to promote IT services to individuals as well as companies. They investigate the effect of marketing stimuli in the form of free trial and price of using IS on consumers' acceptance decision process. Moreover, they provide a theoretical model that integrates user adoption and consumer purchasing behaviour study under a free trial marketing strategy context. The results reveal that trial experience has an impact on post-trial beliefs and attitude and perceived fee would directly and significantly influence consumers purchase intention for paid IT.

Yen, Hsu, and Chang attempt to address the importance of bidders' repurchase intention along with the corresponding cost and benefit aspects toward the online auction market. Furthermore, they examine the factors that drive bidders toward a repurchase intention in the $\mathrm{C} 2 \mathrm{C}$ online auction marketplace. Finally, they provide an integrated model in order to predict and explain a bidder's repurchase intention considering both transaction cost and the satisfaction of bidders. Findings show that satisfaction has a significant influence on bidders' repurchase intentions, while transaction cost is negatively associated with repurchase intentions.

Lee and Park, address the emergence of mobile portal services. There are many essentials factors in the literature that are commonly accepted as being able to help portal sites succeed in the mobile environment. However, the authors concentrate on two important factors: the quality of the site and the brand equity of the portal sites. Authors compare the effect of these factors on the user's trust and intention to use mobile portal services. Results shown that user's trust in the mobile services of portal sites is related to the site's quality and the site's brand equity significantly and that it is an important mediator to increase the user's intention to use mobile portal services.

Kostoglou, Minos and Tolis present the development of an information system capable to provide users the capability to identify a fish species by making consecutive selections relevant to species' external morphology. This system is a fully interactive one, and gives the ability to insert a new identified fish species, extending the entire structure of the information which is stored in the system. Functions such as the presentation of information based on the fish systematic taxonomy and the update capability are some of the additional attributes that make this application user-friendly.

Lai, Kan and Ulhas focus on how user participation and trust drive e-business value. Both participation and trust were found to be critical factors influencing e-business value. Their results support that user participation has the most significant direct impact on trust. Moreover, they prove that trust affects directly e-business satisfaction, and indirectly affects it through e-business readiness and e-business benefits. They proceed by proposing a model for helping managers to implement e-business successfully.

$\mathrm{Hsu}, \mathrm{Wu}$ and Chen focus on the role of experience flow for understanding the antecedents and consequences of flow. Then, they integrate perceived usefulness, perceived ease of use, regulatory fit, e-satisfaction and e-loyalty to construct a research model which confirms that flow is the strongest determinant of e-satisfaction and e-loyalty. Their findings imply that when customers experience 
flow during e-shopping, they will generate feeling of satisfaction and loyalty towards the website.

Papaioannou, Assimakopoulos, Sarmaniotis and Georgiadis, try to evaluate determinants of customer's satisfaction, with service quality dimensions, particularly in the case of e-Bay. More specifically, they investigate buyers' expectation and perception levels towards service quality of e-Bay, they propose determinants of e-Bay service quality, and finally they examine consumption attitudes and behavior of Greek buyers over e-Bay. They proceed by proposing a theoretical model based on the one hand on some dimensions of users' disconfirmation and on the other hand on the factors influencing the users' satisfaction over e-Bay experience.

We sincerely hope that researchers, academics and practitioners, will benefit from the high quality research and practice reflected in these articles.

We would like to take the opportunity to thank Prof. Dr. Jörg Becker, Founding Editor, and Michael J. Shaw, Editor-in-Chief of the ISeB journal for offering them the opportunity to compile and edit this special issue. We would like also, to thank the authors for their efforts in writing and then revising their papers. We thank Springer Journals Editorial Office for the great collaboration throughout the all stages of the process on this special issue. Finally, we are also very grateful to the reviewers for their dedication in reviewing the papers and providing the authors with substantial feedback.

\section{References}

Chen J, Park Y, Putzer GJ (2010) An examination of the components that increase acceptance of smartphones among healthcare professionals. Electron J Health Inf 5(2):e16

Chen K, Chen JV, Yen DC (2011) Dimensions of self-efficacy in the study of smart phone acceptance. Comput Stand Interfaces 33:422-431

Cho N, Park S (2001) Development of electronic commerce user-consumer satisfaction index (ECUSI) for Internet shopping. Ind Manage Data Syst 101(8):400-406

Davis FD (1989) Perceived usefulness, perceived ease of use and user acceptance of information technology. MIS Q 14:319-340

Davis FD, Bagozzi RP, Warshaw PR (1989) User acceptance of two theoretical models. Manage Sci 36:982-1003

King WR, He J (2006) A meta-analysis of the technology acceptance model. Inf Manage 43:740-755

Lee H-J, Lim H, Jolly LD, Lee J (2009) Consumer lifestyles and adoption of high-technology products: a case of South Korea. J Int Consum Marketing 21(2):153-167

Lu HP, Su PY-J (2009) Factors affecting purchase intention on mobile shopping web sites. Internet Res $19(4): 442-458$

Park Y, Chen JV (2007) Acceptance and adoption of the innovative use of smartphone. Ind Manage Data Sys 107(9):1349-1365

Pathasarathy M, Bhattacherjee A (1998) Understanding post-adoption behavior in the context of online services. Inf Sys Res 9(4):362-379

Tams S (2010) Toward holistic insights into trust in electronic markets: examining the structure of the relationship between vendor trust and its antecedents. Inf Syst e-Bus Manage 10(1):149-160

Venkatesh V, Morris MG, Davis GB, Davis FD (2003) User acceptance of information technology: toward a unified view. MIS Q 27(3):425-478 